高校生と大学生の自転車競技選手における下肢と体幹の筋厚が

実走および固定自転車でのスプリント能力に及ぼす影響

\author{
石井 泰光 ${ }^{1}$, 黒川 剛 ${ }^{2}$, 荒木 就平 $^{3}$, 山本 正嘉 ${ }^{4}$
}

\title{
The relationship between muscle thickness of leg and trunk and the sprint performance in the field and on the cycle ergometer in high school and college students cyclists
}

\author{
Yasumitsu Ishii ${ }^{1}$, Takeshi Kurokawa ${ }^{2}$, Syuhei Araki ${ }^{3}$ and Masayoshi Yamamoto ${ }^{4}$ \\ ${ }^{1}$ 国立スポーツ科学センタースポーツ科学研究部， ₹115-0056 東京都北区西が丘 3-15-1 (Department of Sports Science, \\ Japan Institute of Sports Sciences, 3-15-1 Nishigaoka, Kita-ku, Tokyo 115-0056, Japan) \\ 2 鹿屋体育大学スポーツ・武道実践科学系, † 891-2393 鹿览島県鹿屋市白水町 1 番地 (Coaching of Sports and Budo, Na- \\ tional Institute of Sports and Fitness in Kanoya, 1 Shiromizucho, Kanoya, Kagoshima 891-2393, Japan) \\ ${ }^{3}$ 鹿児島県立南大隅高校， ７893-2501 鹿児島県訮属郡南大隅町根占川北413 番地 (Kagoshima Prefectural Minamiosumi \\ High School, 413 Nejimekawakita, Minami-Osumi cho, Kimotsuki-gun, Kagoshima 893-2501, Japan) \\ ${ }^{4}$ 鹿屋体育大学スポーツ生命科学系, \% 891-2393 鹿児島県鹿屋市白水町 1 番地 (Sports and Life Science, National Institute \\ of Sports and Fitness in Kanoya, 1 Shiromizucho, Kanoya, Kagoshima 891-2393, Japan)
}

\section{Received: October 23, 2015 / Accepted: March 30, 2016}

\begin{abstract}
The 30-seconds all-out sprint test on the cycle ergometer was performed by 10 high school and 13 college men's cyclists. In addition, this study investigated their best time for 200 $\mathrm{m}(200 \mathrm{mTT})$ and $1000 \mathrm{~m}(1000 \mathrm{mTT})$ time trials in the velodrome. This study clarifies the relationship between muscle thickness of thigh, shank, and trunk and 1) the average speed for the $200 \mathrm{mTT}$ and 2) the $1000 \mathrm{mTT}$ in the field, and 3) the mean power of the 30 -seconds all-out sprint cycling test. 1) The average speed for the $200 \mathrm{mTT}$ significantly correlated with the muscle thickness of posterior shank and front and lateral abdomen. 2) The average speed for the $1000 \mathrm{mTT}$ significantly correlated with the muscle thickness of posterior thigh and shank and front and lateral abdomen. 3) The mean power of the 30-seconds all-out sprint cycling test significantly correlated with the muscle thickness of anterior and posterior thigh, posterior shank, and front and lateral abdomen. Except for the average speed for the $200 \mathrm{mTT}$ and $1000 \mathrm{mTT}$, the mean power of the 30-seconds all-out sprint cycling test was significantly related to the muscle thickness of anterior thigh. These results suggest that increasing muscle thickness of posterior thigh and shank and front and lateral abdomen is important for enhancing performance in sprint cycling.
\end{abstract}

Jpn J Phys Fitness Sports Med, 65(3): 327-335 (2016)

Keywords : ultrasonic echocardiography, track cycling, power, Wingate test

緒言

自転車競技トラックレースは, 走行距離 $1000 \mathrm{~m}$ を境に, 短距離種目と中距離種目に分類されている ${ }^{11}$ 。短距離種 目としてスプリント，その予選で行われる $200 \mathrm{~m}$ タイム トライアル (以下, $200 \mathrm{mTT}$ ), チームスプリント, ケイ リン, $1000 \mathrm{~m}$ タイムトライアル（以下, 1000mTT) が行 われている。 その中でも $200 \mathrm{mTT} と 1000 \mathrm{mTT}$ とは短距 離種目のパフォーマンスを表す代表的な種目である.

200mTTと $1000 \mathrm{mTT}$ のいずれにおいても，パフォー マンスを高める上では最大速度を高めることが重要であ
る2,3)，そして $1000 \mathrm{mTT}$ T゙は追加条件として，スタート から $250 \mathrm{~m}$ 区間までの平均タイムを短縮すること ${ }^{3-5)} も$ 重要とされる.

この能力を高めるためには，下肢や体幹の筋力および パワーに優れることが必要である。先行研究を見ると, 等速性筋力 (膝関節伸展 ${ }^{6}$, 体幹屈曲 ${ }^{7}$ ), 垂直跳 ${ }^{8,9)}$, レジ スタンストレーニングのパワー系エクササイズ（クリー ンプル ${ }^{9)}$ ，パワークリーン $\left.{ }^{9,10)}\right)$ で評価される筋力拈よび パワーに優れているほど，自転車エルゴメーターもしく は実走によるスプリント能力が高いと報告されている.

ところで筋力ゃパワーに優れるための必要条件とし 
て，下肢や体幹の筋量が大きいことがあげられる。この 点に関する研究として, 池田ほか ${ }^{11}$ は, 国内トップレベ ルの自転車競技選手を対象に，大腿部抢よび体幹の筋横 断面積と 3 種類の負荷条件による 10 秒間の全力ペダリ ングを行わせて，そのパフォーマンスとの関係について 検討し, 大腿四頭筋, 八ムストリングス, 大腰筋, 腹斜 筋群の筋横断面積と, 各負荷条件における平均パワーと の間に有意な相関関係が見られたと報告している。ただ し,これらの結果は, 自転車エルゴメーターによる運動 で得られた結果であり, 実走パフォーマンスとの関倸に ついては検討されていない.この点について, 自転車エ ルゴメーターのパフォーマンスとも併せて検討すること は, 自転車競技トラックレースの短距離種目のパフォー マンス向上を考える上で意義があると考えられる.

そこで本研究では, 男子高校生および男子大学生の自 転車競技選手を対象として, (1) $200 \mathrm{mTT}$, (2) 1000mTT, (3)自転車エルゴメーター30秒間全力運動, という3つ のスプリント能力に対して, 下肢䇽よび体幹の筋厚との 間に, どのような関連性があるかについて検討すること を目的とした。

\section{方 法}

対象者 自転車競技を専門としている男子高校生 10 名, 男子大学生 13 名を対象とした. Table 1 に, 対象者の身 体特性および競技年数を示した。対象者は, 全国高等学 校総合体育大会, もしくは全日本大学対抗選手権に出場 しているレベルであった. 対象者抒よびその保護者には, 本研究の趣旨㧍よび内容, 実験の参加に伴う危険性につ いて説明を行い，書面にて同意を得た。なお，本研究は 鹿屋体育大学の倫理審査小委員会に倫理審査申請書を提 出して, 承諾を受けた（第9-11号）。

測定方法 本研究は, 2012年11月中旬, 2013年 10月下旬, 2013年11月上旬に, (1)形態㧍よび筋厚の測定, (2)自転車 エルゴメーターを用いた 30 秒間全力ペダリングを行っ た. 上記の計測日から, 過去 7 ケ月から 1 ケ月以内に行 われた（測定年度の $5 \sim 11$ 月），地区の記録会および公 式競技会で計測された200mTTおよび1000mTTのべス トタイムを採用した。なお，200mTT拈よび $1000 \mathrm{mTT}$ に使用したギア比は，任意として規定しなかった。

形態および筋厚測定 身長は, 身長計を用いて $0.1 \mathrm{~cm}$ 単 位で計測した，体重掞よび体脂肪率は，デュアル周波数 体組成計（DC-320, 夕ニタ社製, 日本）もしくは体成分 分析装置（InBody720, バイオスペース社製，日本）を用 いて計測した。

筋厚の計測には，超音波診断装置（Prosound2, Aloka 社製，日本）のBモード画像により計測した。測定時の
超音波発信周波数は7.5 MHzであった。測定部位は，大 腿前部, 大腿後部, 下腿前部, 下腿後部, 腹直筋, 腹斜 筋から計測した。測定点は, 安部と福永の方法 ${ }^{12)}$ に従い, 測定時の姿勢は立位とした。 大腿部（前部・後部）は近 位から $50 \%$ 部位とした。 下腿部（前部・後部）は, 近位 から 30\%部位とした，腹直筋は臍部の高さとして, 左右 の腹直筋の筋腹を計測した。腹斜筋は腸骨陵上部の位置 を計測して, 外腹斜筋と内腹斜筋の筋厚を合計した.

上記の方法で計測した超音波画像を用いて，大腿部の 筋厚は, 皮下脂肪組織と筋組織との境界線を示す反射波 から大腿骨までとした。下腿部の筋厚は, 皮下組織と筋 膜の境界を示す反射波から, 深層にある後脛骨筋と前脛 骨筋の境界にある筋膜までとした。測定は, $0.5 \mathrm{~mm}$ 単位 で計測した，筋厚は左右の計測を行ったが，左右両方の 平均值を分析に用いた。な拉，大腿前部は，大腿直筋と 中間広筋の筋厚を合計した，大腿後部は，大腿二頭筋の 筋厚とした。下腿前部は前脛骨筋として，下腿後部は腓 腹筋の外側頭とヒラメ筋の筋厚を合計した。

30 秒間全カペダリング 対象者には，ローラー台を使 用するか, 自転車エルゴメーターを用いて, 十分なウォー ミングアップを行わせた，自転車エルゴメーター（本体： Powermax-VIII, コンビウェルネス社製, 日本; サドル 抢よびハンドル部分：パワーマックス改造 II 型競輪仕様, ヴィクトジャパン，日本）を用いた。対象者の体格に合 わせて, サドルおよびハンドルの位置を調整して， ロー ド用ビンディングペダルを使用して行わせた．

対象者には, ウォーミングアップを兼ねて, 体重の $7.5 \%$ の負荷条件で, 10 秒間の全力ペダリング運動を 1 回実施 させた，10分以上の休息を挟んだ後に，30秒間全力ペダ リングを同負荷条件で実施させた. 30秒間全力ペダリン グの規定条件は，10秒間全力ペダリングで得られた最大 回転数の $95 \%$ 以上を満たすように, 最大努力で行うよう に指示した，上記の規定した最大回転数を満たさない場 合は，10分以上の休息を挟んだ後に再試行を行わせた。

測定值は, 30 秒間の平均パワーおよび最大パワー（絶 対值と体重割）を採用した。測定中の最大回転数につい て求めた。 低下率 (Fatigue Index) は, [(最大パワー25〜30秒区間の平均パワー)/最大パワー］×100によっ て算出した.

統計処理 各分析項目は, 平均值士標準偏差で示し た。高校生と大学生の比較を行うために, 対応のない T検定を用いて，身体特性抢よび競技年数（Table 1), 200mTT打よび1000mTTのタイム拈よび平均速度, 30 秒間全力ペダリングに扔ける最大パワー, 平均パワー, 最大回転数, 低下率を比較した.

下肢拉よび体幹の筋厚と 30 秒全力ペダリングの平均 
パワー（Fig. 1）および200mTTおよび1000mTTの平均 速度（Fig. 2, Fig. 3）との関係について検討するために, ピアソンの積率相関係数を用いた。 なお, 腹斜筋の筋厚 は，全対象者のデー夕を取得することができなかったた め, 高校生は 6 名, 大学生は 12 名, 全体で 18 名のデー 夕を用いて検討した。すべての検定は，JMP9.0.3（SAS Institute Japan）を用いて, 有意水準を $5 \%$ 未満とした。

\section{結 果}

Table 1は，対象者の身体特性と競技年数を示したも のである。 大学生は, 年齢, 競技年数, 身長, 体重, 除 脂肪体重で高校生よりも有意に大きかった。体脂肪率に ついては大学生の方が高校生よりも小さいが, 体脂肪量
には差が認められなかった。

Table 2 は, 対象者の $200 \mathrm{mTT}$ と $1000 \mathrm{mTT}$ の平均速 度およびタイムを, Table 3 は 30 秒間全力ペダリングの 最大パワーおよび平均パワー (絶対值, 体重割), 最大回 転数, 低下率を示した。 いずれの項目とも高校生と大学 生とで有意差は認められなかった。

Table 4は, 対象者の下肢および体幹の筋厚を示した。 いずれの部位においても高校生と大学生の間には有意差 が認められなかった。大腿前部に対する大腿後部の筋厚 の割合，下腿前部に対する下腿後部の筋厚の割合におい ても有意差は認められなかった.

Fig. 1は，下肢および体幹の筋厚と 30 秒間全力ペダリ ングの平均パワーとの関係を示した。高校生と大学生を

Table 1. Anthropometric characteristics of high school and college men's cyclists.

\begin{tabular}{|c|c|c|c|c|c|c|}
\hline Subject characteristic & All subjects & High school & College & $\begin{array}{c}\text { High scho } \\
\text { t-ratio }\end{array}$ & $\begin{array}{c}\text { ol vs Col } \\
\text { p-value }\end{array}$ & lege \\
\hline Age (years) & $18.7 \pm 1.9$ & $16.9 \pm 0.6$ & $20.2 \pm 1.1$ & 8.72 & $p<0.01$ & $* *$ \\
\hline He ight $(\mathrm{cm})$ & $171.2 \pm 5.9$ & $167.4 \pm 3.8$ & $174.2 \pm 5.6$ & 3. 31 & $p<0.01$ & $* *$ \\
\hline Body mass $(\mathrm{kg})$ & $65.3 \pm 8.7$ & $60.8 \pm 4.3$ & $68.8 \pm 9.7$ & 2.65 & $p<0.05$ & $*$ \\
\hline Percent body fat (\%) & $13.3 \pm 3.5$ & $15.6 \pm 2.5$ & $11.5 \pm 3.1$ & 3.38 & $p<0.01$ & $* *$ \\
\hline Lean body mass (kg) & $56.6 \pm 7.1$ & $51.3 \pm 3.2$ & $60.7 \pm 6.6$ & 4. 48 & $p<0.01$ & $* *$ \\
\hline Fat mass $(\mathrm{kg})$ & $8.8 \pm 2.9$ & $9.5 \pm 2.0$ & $8.2 \pm 3.3$ & 1. 14 & $p=0.27$ & ns \\
\hline Competitive experience (years) & $3.7 \pm 2.5$ & $2.0 \pm 1.4$ & $5.1 \pm 2.3$ & 3.84 & $\mathrm{p}<0.01$ & $* *$ \\
\hline
\end{tabular}
$\mathrm{p}<0.05^{*}$ $\mathrm{p}<0.01^{* *}$

Table 2. Time and average speed for 200mTT and $1000 \mathrm{mTT}$.

\begin{tabular}{lcccccc}
\hline \multicolumn{1}{c}{ Track cycling performance } & All subjects & High school & College & \multicolumn{2}{c}{$\begin{array}{c}\text { High school vs College } \\
\text { t-ratio }\end{array}$-value } \\
\hline Time for $200 \mathrm{mTT}(\mathrm{sec})$ & $11.9 \pm 0.6$ & $12.2 \pm 0.7$ & $11.8 \pm 0.5$ & 1.62 & $\mathrm{p}=0.12$ & $\mathrm{~ns}$ \\
Time for $1000 \mathrm{mTT}(\mathrm{sec})$ & $72.3 \pm 4.6$ & $74.0 \pm 5.2$ & $70.9 \pm 3.7$ & 1.70 & $\mathrm{p}=0.11$ & $\mathrm{~ns}$ \\
Average speed for $200 \mathrm{mTT}(\mathrm{m} / \mathrm{s})$ & $16.8 \pm 0.9$ & $16.5 \pm 1.0$ & $17.1 \pm 0.8$ & 1.62 & $\mathrm{p}=0.12$ & $\mathrm{~ns}$ \\
Average speed for $1000 \mathrm{mTT}(\mathrm{m} / \mathrm{s})$ & $13.9 \pm 0.8$ & $13.6 \pm 0.9$ & $14.1 \pm 0.7$ & 1.70 & $\mathrm{p}=0.11$ & $\mathrm{~ns}$ \\
\hline
\end{tabular}

TT: time trial

$\mathrm{p}<0.05$ *

$\mathrm{p}<0.01^{\text {** }}$

Table 3. Maximum and mean power, maximum cadence and Fatigue Index during the 30 -seconds all-out sprint cycling test.

\begin{tabular}{|c|c|c|c|c|c|c|}
\hline 30-seconds all-out sprint cycling test & All subjects & High school & College & $\begin{array}{c}\text { High schoc } \\
\text { t-ratio }\end{array}$ & $\begin{array}{l}\text { ol vs Col } \\
\text { p-value }\end{array}$ & \\
\hline Maximum power $(W)$ & $849 \pm 142$ & $801 \pm 79$ & $885 \pm 169$ & 1.45 & $p=0.16$ & ns \\
\hline Mean power $(W)$ & $679 \pm 98$ & $642 \pm 60$ & $708 \pm 113$ & 1.66 & $p=0.11$ & ns \\
\hline Maximum power per body mass $(\mathrm{W} / \mathrm{kg})$ & $13.0 \pm 1.0$ & $13.2 \pm 0.9$ & $12.8 \pm 1.1$ & 0.78 & $p=0.44$ & ns \\
\hline Mean power relative to body mass $(\mathrm{W} / \mathrm{kg})$ & $10.4 \pm 0.7$ & $10.5 \pm 0.5$ & $10.3 \pm 0.8$ & 0.92 & $p=0.37$ & ns \\
\hline Maximum cadence (rpm) & $177 \pm 14$ & $180 \pm 11$ & $175 \pm 15$ & 0.80 & $p=0.43$ & ns \\
\hline Fatigue Index $(\%)$ & $31.5 \pm 6.0$ & $31.9 \pm 5.2$ & $31.1 \pm 6.8$ & 0.31 & $p=0.76$ & ns \\
\hline
\end{tabular}


Table 4. Muscle thickness of leg and trunk.

\begin{tabular}{|c|c|c|c|c|c|c|}
\hline Muscle thickness & All subjects & High school & College & $\begin{array}{c}\text { High schoo } \\
\text { t-ratio }\end{array}$ & $\begin{array}{c}\text { ol vs Col } \\
\text { p-value }\end{array}$ & lege \\
\hline Anterior thigh (mm) & $60 \pm 6$ & $59 \pm 3$ & $61 \pm 7$ & 0.74 & $p=0.47$ & ns \\
\hline Posterior thigh (mm) & $58 \pm 6$ & $59 \pm 4$ & $58 \pm 6$ & 0.16 & $p=0.88$ & ns \\
\hline Anterior shank (mm) & $29 \pm 2$ & $28 \pm 1$ & $30 \pm 2$ & 1.96 & $p=0.06$ & ns \\
\hline Posterior shank (mm) & $70 \pm 5$ & $69 \pm 4$ & $71 \pm 6$ & 1.08 & $p=0.29$ & ns \\
\hline Front Abdomen (mm) & $15 \pm 2$ & $15 \pm 2$ & $16 \pm 2$ & 1.47 & $p=0.16$ & ns \\
\hline Lateral abdomen (mm) & $24 \pm 4$ & $23 \pm 3$ & $24 \pm 4$ & 0.98 & $p=0.34$ & ns \\
\hline Posterior: Anterior thigh muscle thickness rate $(\%)$ & $98 \pm 10$ & $99 \pm 7$ & $97 \pm 12$ & 0.62 & $p=0.54$ & ns \\
\hline Posterior: Anterior shank muscle thickness rate $(\%)$ & $240 \pm 20$ & $243 \pm 21$ & $238 \pm 19$ & 0.63 & $p=0.54$ & ns \\
\hline
\end{tabular}

$\mathrm{p}<0.05$ *

$\mathrm{p}<0.01$ **

合わせた全体で見ると，大腿前部，大腿後部，下腿後部， 腹直筋，腹斜筋の筋厚と 30 秒間全力ペダリングの平均パ ワーとの間には，有意な相関関係が認められた。

Fig. 2 は，下肢および体幹の筋厚と $200 \mathrm{mTT}$ の平均速 度との関係を示した。高校生と大学生を合わせた全体で は, 下腿後部, 腹直筋, 腹斜筋の筋厚と $200 \mathrm{mTT}$ の平均 速度に有意な相関関係が認められた。

Fig. 3 は，下肢および体幹の筋厚と $1000 \mathrm{mTT}$ の平均 速度との関係を示した，高校生と大学生を合わせた全体 では, 大腿後部, 下腿後部, 腹直筋, 腹斜筋の筋厚と $1000 \mathrm{mTT} の$ 平均速度に有意な相関関係が認められた。

\section{考察}

対象者の身体特性および実走パフォーマンス 本研究の 大学生自転車競技選手は, 先行研究7.10)の身長, 体重とほ ぼ同等であったことから，大学生自転車競技選手として は標準的な体格であったと考えられる. 本研究の大学生 自転車競技選手の $200 \mathrm{mTT} の$ タイム（11.8 $0.5 \mathrm{sec）は,}$ 先行研究 ${ }^{10}(11.3 \pm 0.3 \mathrm{sec})$ と比較して, やや遅い傾向に

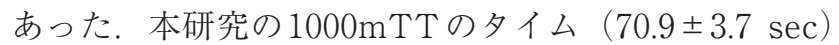
は, 先行研究の大学生自転車競技選手の夕イ 人 $^{7}(75.7 \pm$ $1.9 \mathrm{sec})$ と比較して, やや速い傾向にあった。つまり $200 \mathrm{mTT}$ と $1000 \mathrm{mTT}$ の両方に扔いて, 先行研究の大学 生自転車競技選手と比較して, 同程度のパフォーマンス を有していたと考えられる。

一方，日本国内で開催されている全国大会レベルの競 技会を分析した研究 2 と比較すると, 本研究の $200 \mathrm{mTT}$ のタイムはLow群以下に分類されるレベルであった，本 研究の 1000mTTのタイムは, Low から Moderate群の範 囲にあった。つまり, 本研究の対象者は, 大学生自転車 競技選手としては標準的なレベルであるが，国内の全国 大会から見ると, 200mTT拉よび1000mTT共に, Low およびModerate群に分類されるレベルと考えられる。
本研究の高校生自転車競技選手は, 先行研究の高校生 自転車競技選手 ${ }^{13)}$ と比較して，身長抒よび体重に差が認 められないことから，標準的な体格を有していたと考え られる。高校生の $200 \mathrm{mTT}$ および1000mTTのパフォー マンスを報告した研究は見あたらないが, 本研究の大学 生と比較して統計的に差が認められないパフォーマンス を有していた。

高校生と大学生を比較したところ，30秒間全力ペダ リングの平均パワー（絶対值㧍よび体重割：Table 3), 200mTT拉よび1000mTTの平均速度 (Table 2), さら には下肢㧍よび体幹の筋厚（Table 4）においても有意 差が涩められなかった。したがって本考察では，高校生 と大学生を同等の競技力を持つ一つの集団と見なして, 下肢および体幹の筋厚と 30 秒間全力ペダリングの平均 パワー, $200 \mathrm{mTT}$ および $1000 \mathrm{mTT}$ の平均速度との関係 について検討する。

$200 \mathrm{mTT} ・ 1000 \mathrm{mTT}$ と諸変量との関係 $200 \mathrm{mTT}$ は 10 秒前後, $1000 \mathrm{mTT}$ は 60 秒以上という運動時間や, ス夕 ンディングスタートの有無といった相違点があるが，下 腿後部，腹直筋，腹斜筋の筋厚と，ほぼ同じ筋部位とパ フォーマンスに関連性が認められた。この結果は，標 準的な高校生拉よび大学生の自転車競技選手であれば, 200mTTや1000mTTのパフォーマンスを向上させるた めには, 下腿後部, 腹直筋, 腹斜筋の筋量を増加させる ことが重要であることを意味すると考えられる。

大腿後部の筋厚と $1000 \mathrm{mTT}$ のパフォーマンスとの関 連性が認められた理由は，大腿後部の筋群が股関節伸展 および膝関節屈曲に関与する二関節筋として作用してい たことが影響したと考えられる。自転車エルゴメーター を用いた短時間の全力ペダリングにおいて ${ }^{14,15)}$ ，下肢三関 節のパワー発揮は，ペダリングパワーに対して股関節伸 展が $47 \sim 76 \% ，$ 膝関節伸展が24〜 41\%，足関節底屈が 16 

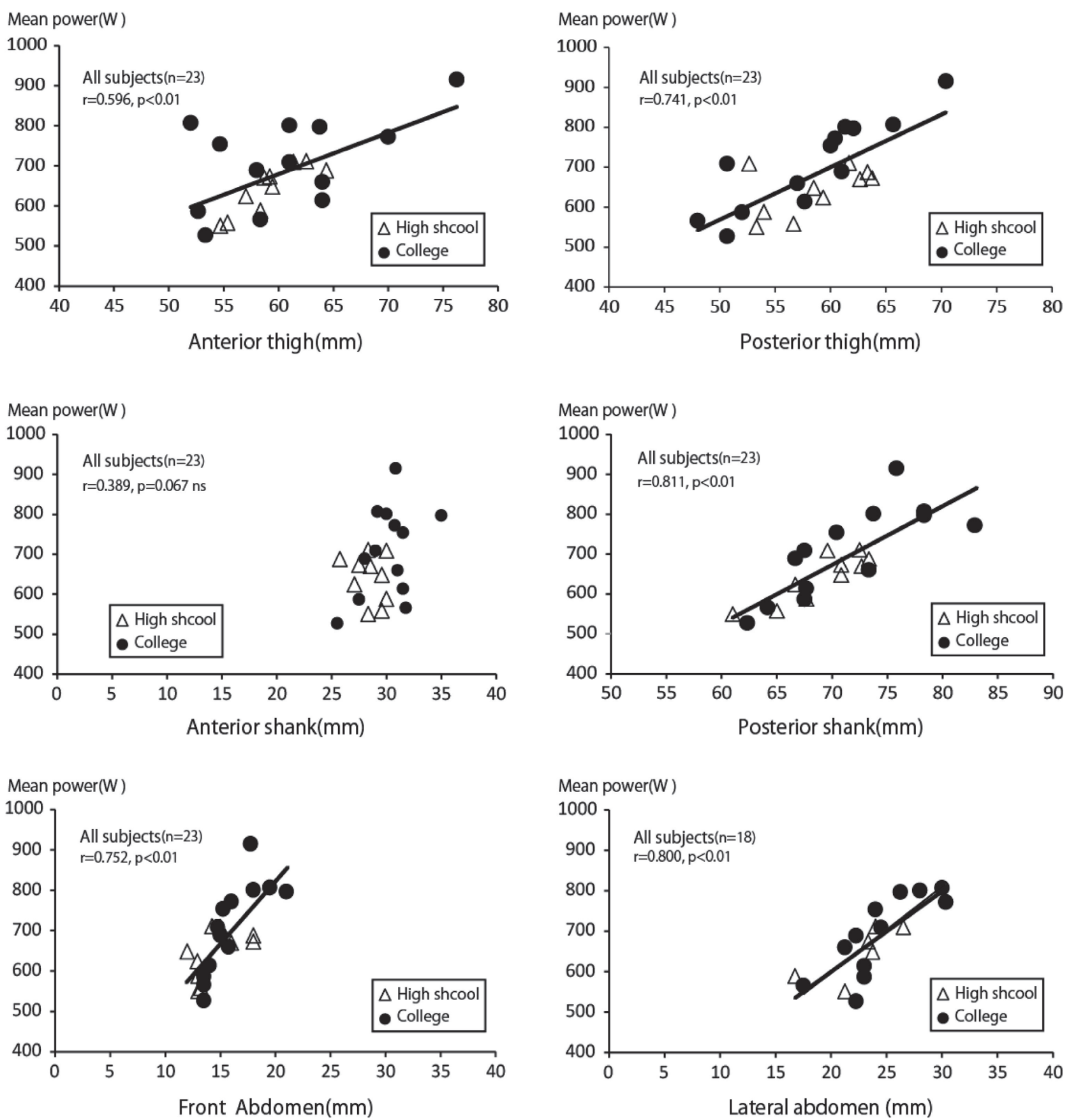

Fig. 1 The relationship between muscle thickness of leg and trunk and mean power during the $30-$ seconds all-out sprint cycling test.

〜35\%を占めており, 股関節伸展パワーは, 膝関節伸展 や足関節伸展のパワーに比べて大きい. また, 最大下運 動から最大運動になると, ペダリングパワーに対する膝 関節伸展パワーが低下して, 膝関節屈曲パワーが増大す ることが報告されている15)。さらに, 短時間の全力ペダリ ングでは, 股関節伸展に関与する大殿筋の筋活動と, 股 関節伸展および膝関節屈曲に関与するハムストリングス の筋活動が増大することが報告されている ${ }^{16)}$.つまり大 腿後部の筋群は, 力学的にも筋活動的にも短時間の全力 ペダリング運動の股関節伸展と膝関節屈曲に大きく関与
していることから関連性が認められたものと考えられる.

一方，大腿後部の筋厚と $1000 \mathrm{mTT}$ の平均速度の間に 有意な相関関係が認められたが，200mTTの平均速度と の間には有意な関係性が認められなかった。その理由の 1 つに，200mTTは1000mTTに比べて走行速度が大き いことから，乗車姿勢による空気抵抗を大きく受けたこ とが影響したと考えられる. Dorel et al.（2005）は，海 外トップレベルの選手を対象に, 自転車エルゴメーター による最大パワーテストの最大パワーと $200 \mathrm{mTT}$ の平 均速度との関係を検討している。最大パワーとの間には 


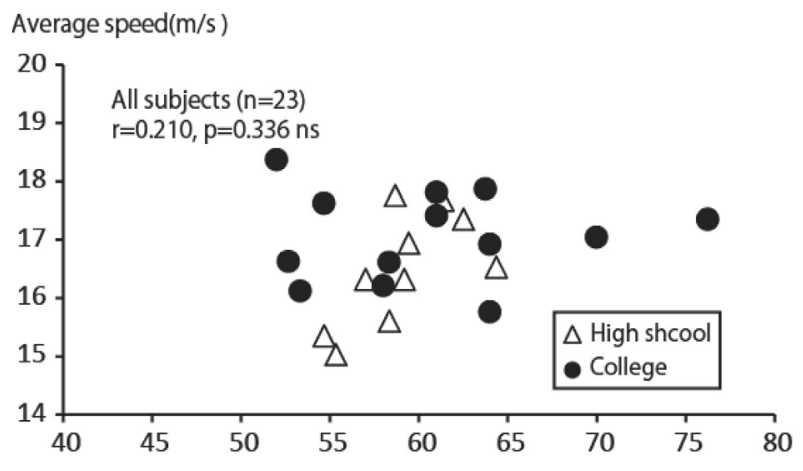

Anterior thigh $(\mathrm{mm})$
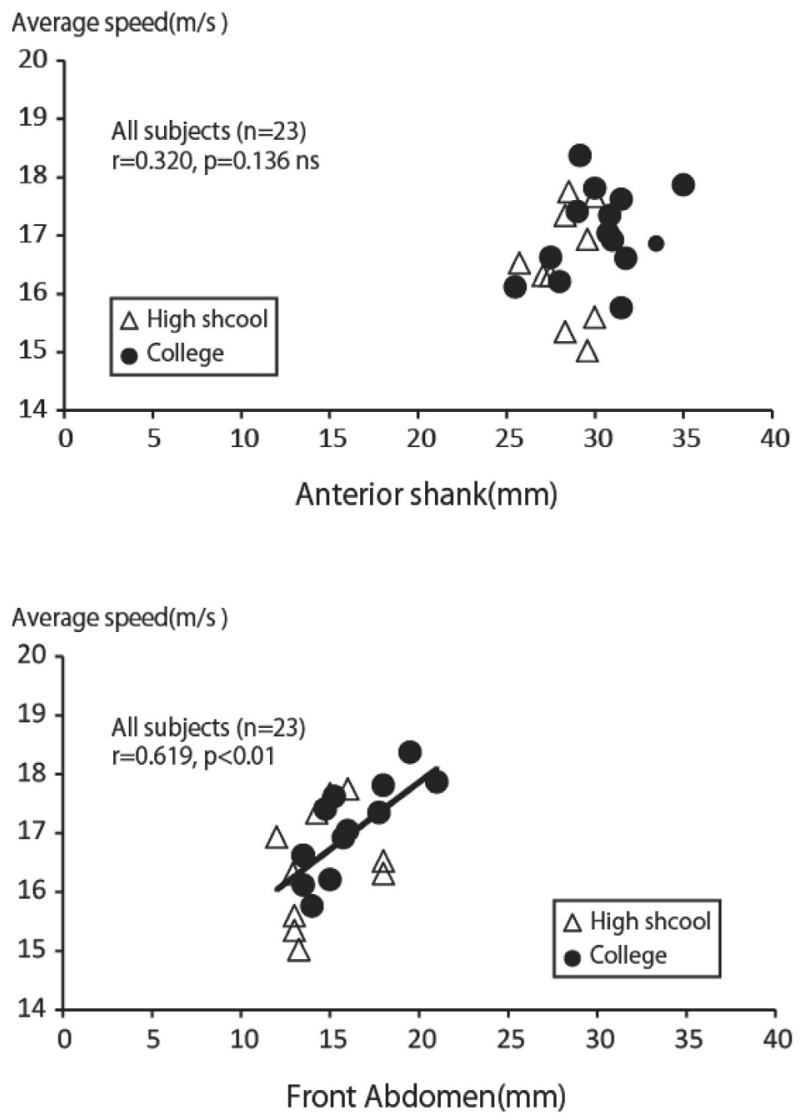

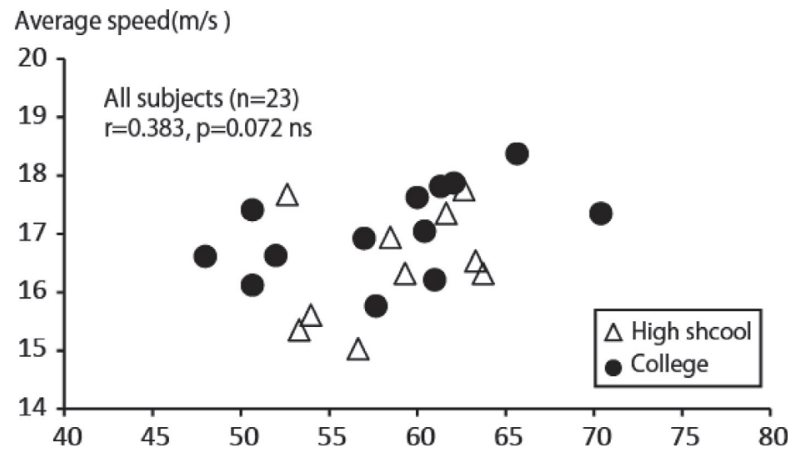

Posterior thigh(mm)
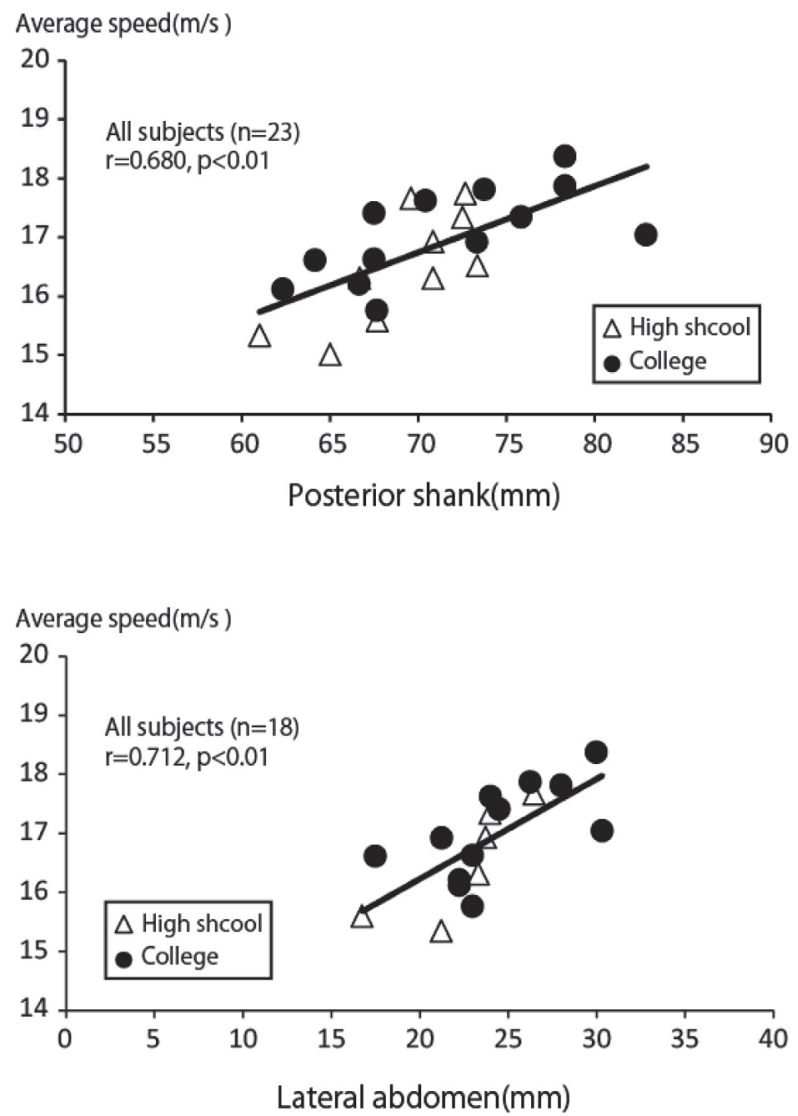

Fig. 2 The relationship between muscle thickness of leg and trunk and average speed for 200mTT.

関連性が認められないが，乗車時の前面投影面積で除し た最大パワーと $200 \mathrm{mTT}$ の平均速度の間に有意な相関 関係を報告している．先行研究と同様に，200mTTのパ フォーマンスは，空気抵抗の影響をより大きく受けるた め, 筋力やパワーを規定する体力要因の 1 つである大腿 後部の筋厚だけでは説明できなくなったため, 関連性が 認められなかったものと推察される.

自転車競技のペダリング動作を対象に，下腿後部の筋 厚と実走能力との関連性を検討した先行研究は見当たら ず，両者の間に関連性があることを示したのは本研究が 初めてである。自転車ペダリング運動において，足関節
は，股関節および膝関節で生じた力をぺダルに伝達する ために重要な部位であると考えられている17)。また、ぺ ダリング中のパワー発揮が大きくなると, 足関節底屈の パワー発揮拉よび筋活動が増大することから ${ }^{16,17)}$ ，股関 節や膝関節からの力をペダルに伝達するだけではなく, 足関節が動力源として機能していることが影響したと考 えられる。

腹直筋および腹斜筋の筋厚と $200 \mathrm{mTT}$ および $1000 \mathrm{mTT}$ の平均速度の間に有意な相関関係が認められ た。この結果は, 先行研究7,11)に扔ける自転車運動のパ フォーマンスと体幹の筋量および筋力に関連性が認めら 

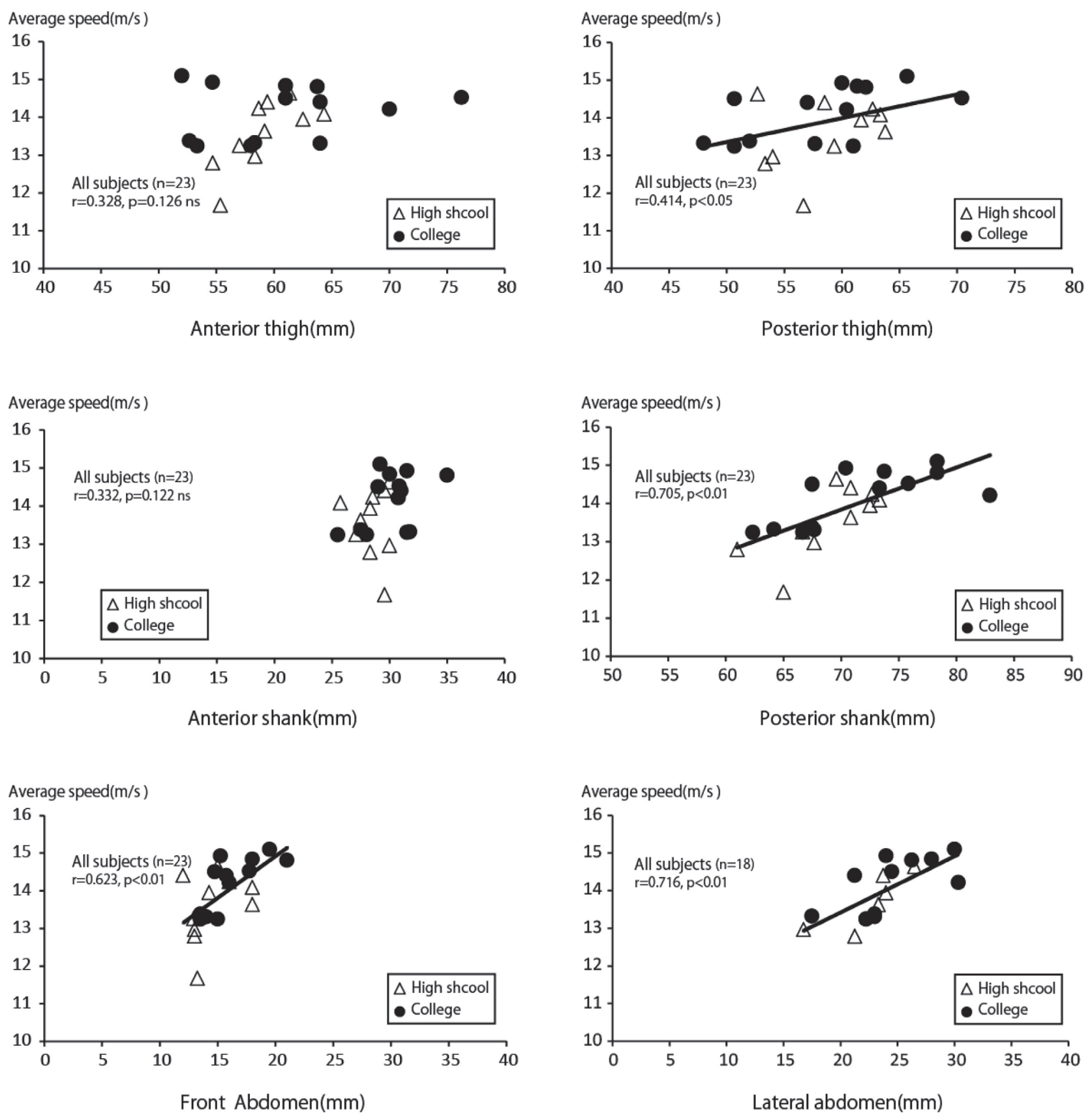

Fig. 3 The relationship between muscle thickness of leg and trunk and average speed for 1000mTT.

れた結果と一致していた。大学生の自転車競技選手を対 象として, 等速性体幹屈曲筋力 $(60 \mathrm{deg} / \mathrm{s})$ と $1000 \mathrm{mTT}$ のタイムに有意な相関関係が報告されている7)。これら の結果は, 実走のパフォーマンスにおいて体幹の筋量が 重要であることを支持していると考えられる.

30 秒間全力ペダリングと諸変量の関係 30 秒間全力ペ ダリングの平均パワーは, 実走と同様に, 大腿後部, 下 腿後部, 腹直筋, 腹斜筋の筋厚との間に有意な相関関係 が認められた。したがって, 実走, エルゴメーターを用 いた運動形態に関わらず，自転車を用いたペダリング運
動では，これらの 4 部位の筋量を増加させることは重要 であると考えられる。一方で，30秒間全力ペダリングの 平均パワーと大腿前部の筋厚との間に相関関係が認めら れる点が異なっていた。自転車エルゴメーターと実走で は, 大腿前部の機能的な役割や，パワー発揮における重 要性が異なる可能性も考えられる。これらの理由の解明 については，今後の検討課題である.

腹斜筋の筋厚と 30 秒間全力ペダリングの平均パワー との間には有意な相関関係が認められた。同様の先行研 究としては，国内トップレベルの自転車競技選手を対象 に, 腹斜筋群 (外側腹筋群) の筋断面積と中・高負荷条 


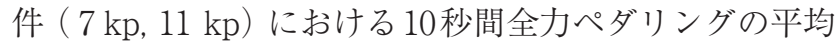
パワーに有意な相関関係が報告されている ${ }^{11)}$. 本研究で は, 運動時間が 30 秒間と長く, 負荷条件 (高校生: $4.5 \pm 0.3$ $\mathrm{kp}$; 大学生 : $5.1 \pm 0.7 \mathrm{kp}$; 全体 : $4.9 \pm 0.7 \mathrm{kp})$ が先行研 究に比べて小さいが, 同様の関連性が認められた。腹斜 筋は, スタートから大きなクランクトルクを発揮できる 姿勢を作るために, 腰椎の回旋や側屈の動きを抑制して いることが推察される. また, 最大回転速度に到達後に, 下肢によって大きなパワー発揮を継続させる姿勢を保つ ためにも，腹斜筋が働いていた可能性も考えられる。し たがって, 腹直筋および腹斜筋は, 実走だけではなく, 自転車エルゴメーターに扔いて, 短時間で大きなパワー 発揮をするために重要な役割を果たしていることが考え られた。

実践現場への示唆 本研究では, 高校生および大学生の 自転車競技選手を対象に, 下肢掞よび体幹の筋厚と自転 車エルゴメーター拈よび実走のパフォーマンスとの関倸 性について検討した。自転車エルゴメーターおよび実走 という運動形態の違いに関わらず, 大腿後部, 下腿後部, 腹直筋, 腹斜筋の筋量を増加させることは, 自転車ぺダ リング中のパワー発揮を高めるには重要であることが明 らかになった。

大腿後部の筋群は，股関節伸展および膝関節屈曲に関 与しており, これらの関節運動は, 自転車ペダリング中 のパワー発揮に対する貢献度も大きいことが知られてい る15,17)。また，本研究に打ける30秒間の全力ペダリング だけではなく, 先行研究の10秒間全力ペダリングにおい ても，大腿後部（ハムストリングス）の筋量とペダリン グ中のパワー発揮との間に関連性が認められている ${ }^{11)}$. したがって, 自転車ペダリング運動において, 大腿後部 の筋量を増加させることは, 自転車ペダリング軍動にお いて短時間で大きなパワーを発揮するためには重要であ ると考えられる.

大腿後部の筋量を増やすには、レッグカールのような 膝関節屈曲の単関節動作だけではなく, スクワットや デットリフトといった股関節の伸展屈曲が含まれる多関 節運動によるエクササイズを選択することが有効である と考えられる。ささらに, 自転車エルゴメーターと実走に 共通して, 大腿後部は大腿前部の相関係数に比べて大き い傾向が認められた，運動形態に関わらず，自転車ぺダ リング運動のパワー発揮を向上させるためには, 大腿後 部の筋群を優先的に強化することが重要であると考えら れる。

下腿後部の筋量は，自転車エルゴメーターおよび実走 に関わらず高い相関関係が認められた。自転車ペダリン グ運動において，パワー発揮を増大させるためには，足 関節底屈のパワー発揮の重要性を示した研究は見あたら
ない，全体のパワー発揮に対して，股関節や膝関節に比 べれば足関節の関与は小さいが, 足関節にも着目してト レーニングを実施していくことが重要であることを示唆 していると考えられる。

腹直筋拧よび腹斜筋は，体幹の屈曲，側屈・回旋に関 与する筋群である。腹直筋が関与する等速性体幹屈曲筋 力と $1000 \mathrm{mTT}$ のパフォーマンスとの間に関連性が認め られており ${ }^{7)}$ ，腹斜筋の筋横断面積と中・高負荷条件に おける自転車エルゴメーターのパワー発揮特性 ${ }^{11)}$ の間に 関連性が認められていることから, 先行研究の結果を支 持する結果となった。

$1000 \mathrm{mTT}$ は, 腹斜筋や腹直筋が機能することによっ て，骨盤扮よび腰椎の回旋を防き，体幹屈曲の姿勢を保 ち, スタート局面から大きなパワー発揮を可能にして, 乗車中の体幹の摇れを抑えるために働いていると推察さ れる. 200mTTでは, トラックレース短距離種目の中で, 最も速度が大きいことから，コーナー部分で大きな加速 度を受けるため, 腹直筋や腹斜筋が働くことで, 適切な 乗車姿勢を保ち，スムーズなペダリングを行うことに貢 献していることが予想される。しかし，実走の自転車ぺ ダリング運動を対象に，体幹の筋群がどのように機能し ているのか検討した研究は見あたらないことから，今後 の検討課題であると考えられる.

実走の 200mTT および1000mTTといった運動時間が 異なる種目に扔いて, 腹直筋と腹斜筋の両方に関連性が 見られた結果は, 本研究が初めての結果である.したがっ て, 高校生や大学生の自転車競技選手では, 腹直筋だけ ではなく, 腹斜筋も含めて, 様々な方向から体幹の筋量 および筋力を強化していくことが重要であることを示し ている。

本研究では, これまであまり着目されてこなかった下 腿や体幹の筋量の重要性を示したことに意義があると考 えられる。また実走では，大腿後部の筋量がパフォーマ ンスに大きく影響する可能性も示唆された。これらの知 見は自転車競技のレジスタンストレーニングをプログラ ム作成時の参考になると考えられる。

なお，自転車競技選手は，室内でスプリント能力を改 善するためのトレーニング手段として自転車エルゴメー ターを用いている。 また，体力測定にも用いられること がある、本研究の結果から, 自転車エルゴメーターで動 員される筋群は実走とほぼ同等であることが明らかに なった。一方で, 実走と比較して大腿前部の筋群と関連 性が認められたことから, 実走に比べて大腿前部の筋群 がより動員される可能性も示唆された。自転車エルゴ メーターを用いてトレーニングや体力測定を実施する際 には，上記のように実走とはやや異なる性質があること も念頭に置いて行うことが必要と考えられる. 


\section{まとめ}

10 名の男子高校生および13名の男子大学生の自転車 競技選手を対象として, (1)実走による200mTTの平均速 度, (2) 1000mTTの平均速度, (3)自転車エルゴメーター による 30 秒間全力ペダリングの平均パワーという 3 種 類のパフォーマンスに対し，下肢および体幹の筋厚が, どのような関係性を示すかを検討し，以下の知見を得た。 1） $200 \mathrm{mTT}$ のパフォーマンスに対しては, 下腿後部, 腹直筋, 腹斜筋との間に有意な相関関係が認められた。

2 ） 1000mTTのパフォーマンスに対しては, 大腿後部, 下腿後部，腹直筋，腹斜筋との間に有意な相関関係が 認められた。 $200 \mathrm{mTT}$ と同様の部位に関係性が認めら れたことに加え，大腿後部の筋厚との間にも関連性が 認められた。

3） 30 秒間全力ペダリングのパフォーマンスに対し ては，大腿前部，大腿後部，下腿後部，腹直筋，腹 斜筋の筋厚との間に有意な相関関係が認められた。 200mTTおよび1000mTTのパフォーマンスとの間に 認められなかった，大腿前部の筋厚との間にも関連性 が認められた。

以上から，自転車競技場で行われる実走による 200mTTおよび1000mTTの平均速度を高めるには，大 腿後部, 下腿後部, 腹直筋, 腹斜筋の筋量を高める重要 性が明らかになった。また，自転車エルゴメーターでの スプリント能力に寛容する部位の共通点や相違点も明ら かとなった。これまで自転車競技の研究や指導現場では 大腿部の重要性は認識されてきたが, 本研究の結果から, 自転車トラックレース短距離種目で高いパフォーマンス を発揮するには大腿後部の筋量だけではなく，下腿や体 幹の筋量にも着目することが重要と考えられた。

利益相反自己申告：申告すべきものはなし

\section{謝 辞}

本研究の実施にあたり，対象者としてご協力をいただい た，南大隅高校自転車競技部および鹿屋体育大学自転車競 技部の皆様に感謝いたします。また，本研究の計測にご協 力をいただきました福永裕子様には，心より御礼申し上げ ます。

\section{文献}

1) Craig NP, Norton KI. Characteristics of track cycling. Sports Med Open 31: 457-468, 2001.

2) 太田洋一, 高嶋 渉, 池田祐介, 貴嶋孝太, 村田正洋 : 自 転車競技（200mFTT，250mTT，500mTT，1 kmTT， $4 \mathrm{kmTT}$ ）における記録とレース中の速度変化特性, ク ランク回転数変化特性およびギア比との関係, トレーニ ング科学, 23: 177-195, 2011.
3）池田祐介, 高嶋 涉, 陸名英二, 村田正洋：2011年自転 車世界選手権大会における男子 $200 \mathrm{~m}$ および $1000 \mathrm{~m}$ 夕 イムトライアルのレース分析, トレーニング科学, 23: 349-360, 2012.

4) de Koning JJ, Bobbert MF, Foster C. Determination of optimal pacing strategy in track cycling with an energy flow model. J Sci Med Sport 2: 266-277, 1999.

5) Corbett J. An analysis of the pacing strategies adopted by elite athletes during track cycling. Int I Sports Physiol Perform 4: 195-205, 2009.

6) Driss T, Vandewalle H, Le Chevalier JM, Monod H. Force-velocity relationship on a cycle ergometer and knee-extensor strength indices. Can J Appl Physiol 27: 250-262, 2002.

7）池田祐介, 高嶋 涉, 谷所 慶, 前川剛輝, 西山哲成：トラッ ク種目を専門とする一流自転車競技選手と大学自転車 競技選手の体力要素の比較および大学自転車競技選手 の $1 \mathrm{~km}$ タイムトライアルにおけるパフォーマンスと体 力要素の関係, トレーニング科学, 21: 399-416, 2009.

8) Vandewalle H, Peres G, Heller J, Panel J, Monod H. Force-velocity relationship and maximal power on a cycle ergometer. Correlation with the height of a vertical jump. Eur J Appl Physiol Occup Physiol 56: 650656, 1987.

9) Stone MH, Sands WA, Carlock J, Callan S, Dickie D, Daigle K, Cotton J, Smith SL, Hartman M. The importance of isometric maximum strength and peak rateof-force development in sprint cycling. J Strength Cond Res 18: 878-884, 2004.

10）石井泰光, 木村亜美, 黒川 剛, 山本正嘉：自転車競技選 手におけるパワークリーンおよびスクワットの最大挙 上重量と短距離走行能力との関係, スポーツパフォーマ ンス研究, 6: 175-183, 2014.

11）池田祐介, 高嶋 渉, 本間俊行, 高橋英幸, 村田正洋：男女 一流自転車競技選手における筋の形態的特徵と自転車 エルゴメータのパワー発揮能力との関係, 体育学研究, 58: 539-555, 2013.

12）安部 孝, 福永哲夫. 6 章 超音波が描いた皮下脂肪組織 之筋組織, 日本人の体脂肪之筋肉分布, 杏林書院, 東京, 91-108, 1995.

13）綱分憲明, 田原靖昭, 湯川幸一, 千住秀明：高校男子自転 車競技優秀選手の身体組成, 最大酸素摂取量及び最大酸 素負債量, Ann Physiol Anthropol 12: 351-362, 1993.

14) Martin JC, Brown NA. Joint-specific power production and fatigue during maximal cycling. $J$ Biomech 42 : 474-479, 2009.

15) Elmer SJ, Barratt PR, Korff T, Martin JC. Joint-specific power production during submaximal and maximal cycling. Med Sci Sports Exerc 43: 1940-1947, 2011.

16) Dorel S, Guilhem G, Couturier A, Hug F. Adjustment of muscle coordination during an all-out sprint cycling task. Med Sci Sports Exerc 44: 2154-2164, 2012.

17) Elmer SJ, Marshall CS, Wehmanen K, Amann M, McDaniel J, Martin DT, Martin JC. Effects of locomotor muscle fatigue on joint-specific power production during cycling. Med Sci Sports Exerc 44: 1504-1511, 2012. 